\title{
Pemetaan dan Kesesuaian Lahan Tanaman Pangan di DAS Krueng Pasee Kabupaten Aceh Utara
}

\author{
Samsul Suparno ${ }^{1}$, Halim Akbar ${ }^{1}$ dan Muhammad Rafli ${ }^{1}$ \\ Email: halim-akbar@unimal.ac.id
}

\begin{abstract}
Abstrak
Pemetaan dengan menggunakan Sistem Informasi Geografis (SIG) pada tanaman pangan merupakan suatu cara yang efisien dan efektif untuk mengetahui karakteristik lahan dan potensi pengembangannya dalam menentukan kelas kesesuaian lahan pada suatu wilayah. Penelitian ini bertujuan untuk menentukan kelas kesesuaian lahan tanaman pangan pada Daerah Aliran Sungai (DAS) Krueng Pase Kabupaten Aceh Utara, yang dimulai dari bulan Desember 2016 sampai bulan Maret 2017. Metode yang digunakan dalam penelitian ini adalah metode survei yang terdiri dari tahap persiapan, survei pendahuluan, survei utama, analisis data serta penyajian hasil. Beberapa sifat tanah yang mempengaruhi kelas kesesuaian lahan untuk tanaman pangan yaitu tekstur tanah, kapasitas tukar kation (KTK), pH, kejenuhan basa (KB), C-organik, Nitrogen, Fosfor dan Kalium. Hasil penelitian menunjukkan bahwa kelas kesesuaian lahan untuk padi sawah tadah hujan pada SPL 29, SPL 30 dan SPL 31 adalah sesuai marginal (S3) dengan faktor pembatas drainase, fosfor, kalium, lereng dan bahaya erosi. Kelas kesesuaian lahan tidak sesuai $(\mathrm{N})$ dengan faktor pembatas lereng dan bahaya erosi terdapat pada SPL 26. Kelas kesesuaian lahan untuk tanaman jagung dan kedelai adalah sesuai marginal (S3) dengan faktor pembatas tekstur, C-organik, fosfor, kalium, lereng dan bahaya erosi yang terdapat pada SPL 9, SPL 10, SPL 12, SPL 13, SPL 14, SPL 16, SPL 17, SPL 18, SPL 20, SPL 21, SPL 22, dan SPL 23. Sedangkan kelas kesesuaian lahan tidak sesuai $(\mathrm{N})$ dengan faktor pembatas lereng dan bahaya erosi terdapat pada SPL 15. Adapun teknik konservasi tanah yang disarankan yaitu pembuatan saluran drainase, pemberian pupuk organik dan an-organik yang dikombinasikan serta pembuatan teras guludan.
\end{abstract}

Kata kunci: Pemetaan, Kesesuaian Lahan, Watershed, Konservasi Tanah

\begin{abstract}
Mapping using Geographic Information System (GIS) in food crops is an efficient and effective way to know land characteristics and their development potential in determining land suitability class in a region. This study aims to investigate the suitability class of food crops in the Krueng Pase River Basin (DAS) of North Aceh Regency, which starts from December 2016 until March 2017. The method used in this study is a survey method consisting of the preparation stage, survey introduction, main survey, data analysis and presentation of results. Some soil properties that affect land suitability classes for food crops are soil texture, cation exchange capacity (CEC), $\mathrm{pH}$, basic saturation (KB), C-organic, Nitrogen, Phosphorus and Potassium. The results showed that the land suitability class for rainfed lowland rice on SPL 29, SPL 30 and SPL 31 was marginal (S3) with drainage limiting factor, phosphorus, potassium, slope and erosion hazard. Unsuitable land suitability class $(\mathrm{N})$ with slope limiting factor and erosion hazard is
\end{abstract}

${ }^{1}$ Jurusan Agroteknologi Fakultas Pertanian Universitas Malikussaleh 
found in SPL 26. The soil suitability class for corn and soybean is marginal (S3) with texture limiting factor, C-organic, phosphorus, potassium, slope and hazard (SP), SPL 17, SPL 18, SPL 20, SPL 21, SPL 22 and SPL 23. While the land suitability class is not suitable $(\mathrm{N})$ with slope limiting factor and erosion hazard is found in SPL 15. The suggested soil conservation techniques are drainage drainage, organic and inorganic fertilizer application combined, and the making of guludan terraces.

Keywords: Mapping, Land Suitability, Watershed, Soil Conservation

\section{Pendahuluan}

Tanah adalah lapisan atas bumi yang merupakan campuran dari pelapukan bebatuan dan jasad makhluk hidup yang telah mati dan membusuk, akibat pengaruh cuaca, jasad makhluk hidup tersebut menjadi lapuk kemudian mineralmineralnya terurai, sehingga membentuk tanah yang subur (Saridevi, 2013). Secara fisik tanah berfungsi sebagai tempat tumbuh dan berkembangnya perakaran, menyuplai kebutuhan air dan udara Hanafiah (2005). Sedangkan secara kimiawi tanah berfungsi sebagai gudang hara dan sumber penyuplai hara atau nutrisi (meliputi: senyawa organik dan anorganik sederhana dan unsur-unsur essensial seperti $\mathrm{N}, \mathrm{P}, \mathrm{K}, \mathrm{Ca}, \mathrm{Mg}, \mathrm{S}, \mathrm{Cu}$, $\mathrm{Zn}, \mathrm{Fe}, \mathrm{Mn}, \mathrm{B}$, dan $\mathrm{Cl}$ ).

Pemetaan dengan menggunakan sistem informasi geografis (SIG) merupakan suatu cara yang efisien dan efektif untuk mengetahui karakteristik lahan dan potensi pengembangannya dalam menduga evaluasi kesesuaian lahan suatu wilayah. Kecocokan lahan untuk penggunaan yang telah ditetapkan saat ini atau setelah lahan mengalami perubahan dapat dijelaskan dengan mengevaluasi kesesuaian lahan (Fauzi et al., 2009). Fungsi dari pemetaan ini sendiri adalah memberikan kemudahan dalam memperoleh data, membuat keputusan yang tepat, membuat perencanaan dalam pengembangan wilayah. Disamping itu, juga dapat memberikan informasi yang tepat kepada masyarakat dan petani untuk membuat keputusan mengenai kesesuaian lahan yang ada pada suatu wilayah tersebut (Puntodewo et al., 2010).

Kesesuaian lahan perlu diperhatikan dan dipertimbangkan untuk keberhasilan suatu budidaya tanaman agar nantinya produksi yang diharapkan dapat tercapai secara optimal. Pemanfaatan lahan sebagai sumber daya alam, dan pengembangan suatu komoditas pertanian harus memperhatikan aspek-aspek kelestarian lingkungan yang sesuai dengan potensi lahan tersebut, penggunaan lahan yang tidak sesuai dengan kemampuannya akan menimbulkan terjadinya kerusakan lahan (Abdullah, 1993).

Penggunaan lahan yang hanya mementingkan produksi tanpa mempertimbangkan daya dukungnya akan mengakibatkan lahan terancam rusak dan akan mengganggu keseimbangan ekosistem, sehingga lahan tersebut tidak lagi dapat digunakan secara berkelanjutan. Ditambah lagi kurangnya kesadaran masyarakat untuk memanfaatkan lahan semak belukar yang dinilai dapat menjadi salah satu sumber pendapatan untuk meningkatkan ekonomi masyarakat dari pada hanya dibiarkan begitu saja tanpa dikelola.

Berdasarkan uraian di atas, untuk dapat memanfaatkan lahan secara lestari, tepat dan berkesinambungan serta untuk menghindari resiko penurunan produktifitas lahan akibat penggunaan yang tidak sesuai, maka perlu dilakukan 
penilaian kesesuaian lahan untuk sawah tadah hujan dan tanaman pangan di DAS Krueng Pase Kabupaten Aceh Utara agar dalam pemanfaatannya lebih produktif dan berkelanjutan.

Penelitian ini bertujuan untuk menentukan kelas kesesuaian lahan tanaman pangan di DAS Krueng Pase Kabupaten Aceh Utara.

\section{Bahan dan Metode}

Penelitian ini dilaksanakan di DAS Krueng Pase yang terletak di Kabupaten Aceh Utara dengan jarak 21,1 km dari Kota Lhokseumawe, analisis tanah dilakukan di Laboratorium Ilmu Tanah Universitas Syiah Kuala Banda Aceh. Penelitian lapangan dimulai dari bulan Desember 2016 sampai dengan bulan Maret 2017.

Bahan yang digunakan dalam penelitian ini adalah sampel tanah yang diambil dari lokasi penelitian berdasarkan Satuan Peta Lahan (SPL), serta bahan kimia untuk menganalisa tanah. Sedangkan alat yang digunakan dalam penelitian ini adalah peta jenis tanah (skala 1:100.000), peta penggunaan lahan (skala 1:100.000), peta lereng (skala 1:100.000), abney level, GPS, bor tanah, cangkul, kertas label, kantong plastik, karet gelang dan alat tulismenulis.

Metode yang digunakan dalam penelitian ini adalah metode survei yang terdiri atas 4 (empat) tahap yaitu: 1) tahap persiapan, 2) survei pendahuluan, 3) survei utama, 4) analisis data serta penyajian hasil.

\section{Hasil dan Pembahasan Satuan Peta Lahan}

Satuan peta lahan(SPL) merupakan kumpulan bentang lahan yang memiliki sifat-sifat atau ciri-ciri yang sama. Penentuan satuan peta lahan didasarkan pada sifat-sifat karakteristik lahan yang mudah dipetakan seperti lereng (relief), bentuk lahan (landform), jenis tanah, penggunaan lahan dan bahan induk tanah (Hardjowigeno dan Widiatmaka, 2007).
Hasil overlay tiga jenis peta yaitu peta jenis tanah, peta kemiringan lereng dan peta penggunaan lahan di DAS KruengPase Kabupaten Aceh Utara didapat 33 Satuan Peta Lahan (SPL), dimana 17 SPL nantinya menjadi mengamatan intensif.

\section{Hasil Analisis Beberapa Parameter}

Hasil pengambilan, pengukuran dan pengamatan dilapangan menunjukkan bahwa temperatur rata-rata dilokasi penelitian sebesar $26,74{ }^{0} \mathrm{C}$, curah hujan rata-rata sebesar 1910,9 $\mathrm{mm} /$ tahun, lamanya masa bulan kering 3 bulan/tahun, bulan basah 6 bulan/tahun dan rata-rata kelembaban berkisar 84\% (BMKG Aceh Utara, 2016).

Nilai temperatur pada lokasi penelitian ini sangat sesuai untuk padi sawah tadah hujan sedangkan untukjagung dan kedelai cukup sesuai. Kelembaban udara untuk padi sawah tadah hujan dan tanaman jagung sangat sesuai, sedangkan pada tanaman kedelai cukup sesuai.

Hasil pengamatan dan pengukuran dilapangan menunjukkan bahwa drainase untuk padi sawah tadah hujan, jagung dan kedelai (baik-sedang), kedalaman tanah (> $100 \mathrm{~cm}$ ), kemiringan lereng datar sampai berbukit (4-24\%), bahaya erosi (sangat ringan, sedang, ringan), batuan dipermukaan (0-2\%), singkapan batuan (0-1\%). Sedangkan hasil analisis tanah di Laboratorium tanah menunjukkan bahwa tekstur tanah pada kelas liat (halus), lempung berdebu (agak halus), lempung liat berdebu (agak halus), lempung (sedang), lempung berdebu (sedang) dan lempung berpasir (agak kasar) dan untuk C-organik (0,15-2,94\%),

Hasil analisis di Laboratorium menunjukkan bahwa nilai Kapasitas Tukar Kation tanah untuk padi sawah tadah hujan, jagung dan kedelai yaitu sangat sesuai (10,80-39,20 cmol), sedangkan untuk Kejenuhan Basa yang dilihat dari hasil analisis Laboratorium menunjukkan bahwa untuk ketiga tanaman tersebut sangat sesuai sampai cukup sesuai (41,11-69, 39\%), pH agak masam $(5,38)$ 
sampai dengan netral (6,92). Hasil pengukuran pada $\mathrm{pH}$ tanah menunjukkan bahwa sangat sesuai untuk padi sawah tadah hujan, jagung dan kedelai. Ketiga tanaman ini membutuhkan $\mathrm{pH}$ mulai 5,5-7,5 untuk pertumbuhan yang optimal. Nitrogen sedang sampai rendah $(0,13-0,29)$, Fosfor rendah sampai sangat rendah $(0,05-1,57)$ dan Kalium sangat rendah $(0,35-1,04)$

\section{Penilaian Kelas Kesesuaian Lahan}

Hasil penilaian kelas kesesuaian lahan memberikan informasi tentang pemanfaatan dan penggunaan lahan yang sesuai dengan kriteria tanaman. Penilaian kelas kesesuaian lahan merupakan

suatu pendekatan yang penting
dalam mengarahkan penelitian atau evaluasi lebih lanjut untuk usaha pengembangan selanjutnya. Penentuan kelas kesesuaian lahan bagi tanaman yang sedang diteliti atau karakteristik lahan penelitian yang diperlukan dalam evaluasi lahan dicocokkan dengan kriteria kesesuaian lahan padi sawah tadah hujan, jagung dan kedelai untuk mendapatkan kelas-kelas kesesuaian lahannya.

Kelas Keseuaian Lahan untuk Padi Sawah Tadah Hujan

Dari hasil analisis tanah dan pengukuran di lapangan, maka didapat kelas kesesuaian lahan padi sawah tadah hujan sebagai berikut:

Tabel 1. Hasil evaluasi kesesuaian lahan untuk padi sawah tadah hujan di DAS Krueng Pase Kabupaten Aceh Utara

\begin{tabular}{ccl}
\hline No & Satuan Peta Lahan & \multicolumn{1}{c}{ Kelas Kesesuaian Lahan } \\
\hline 1 & 26 & Neh-1,eh-2 \\
2 & 29 & S3na-2,na-3,eh-1,eh-2 \\
3 & 30 & S3nr-4,na-2,na-3 \\
4 & 31 & S3na-2,na-3 \\
\hline
\end{tabular}

Keterangan :nr-4 = C-organik, na-2 = fosfor, na-3 = kalium, eh-1 = Lereng, eh-2 = Bahaya Erosi.

Berdasarkan Tabel 1 di atas dapat dilihat bahwa kelas kesesuian lahan untuk padi sawah tadah hujan di empat SPL penelitian adalah sebagai berikut : kelas kesesuaian lahan pada SPL 26 memiliki kelas kesesuaian lahan tidak sesuai $(\mathrm{N})$ karena mempunyai faktor pembatas yang sangat berat dan sangat sulit untuk diatasi, dengan faktor pembatas lereng (Neh-1) dan bahaya erosi (Neh-2). Pada SPL 29 memiliki kelas kesesuaian lahan sesuai marginal (S3) dengan faktor pembatas yang sangat berat yaitu fosfor (S3na-2), kalium (S3na-3), lereng (S3eh-1) dan bahaya erosi (S3eh-2). Untuk faktor pembatas $\mathrm{P}$ dan $\mathrm{K}$ dapat ditingkatkan dengan cara pemberian pupuk organik dan anorganik dengan cara mengkombinasikan pupuk tersebut secara seimbang. Sedangkan untuklereng dan bahaya erosi dapat diperbaiki dengan teknik konservasi pembuatan teras dengan teras bangku (Hidayat, 2006).

Pada SPL 30 memiliki kelas kesesuaian lahan sesuai marginal (S3) dengan faktor pembatas yang sangat berat yaitu C-organik (S3nr-4), fosfor (S3na-2) dan kalium (S3na-3). C-organik dapat ditingkatkan dengan cara pemberian bahan organik berupa kompos dan pupuk kandang. Sedangkan untuk $\mathrm{P}$ dan $\mathrm{K}$ dapat ditingkatkan dengan cara pemberian pupuk organik dan anorganik. Usaha mengkombinasikan penggunaan pupuk organik dan anorganik yang 
diterapkan pada tanaman padi sawah akan memberikan peluang untuk meningkatkan produksi secara berkelanjutan, (Novizan, 2002).

Sedangkan pada SPL 31 memiliki kelas kesesuaian lahan sesuai marginal (S3) dengan faktor pembatas fosfor (S3na2) dan kalium (S3na-3). Faktor pembatas $P$ dan $\mathrm{K}$ dapat diperbaiki dengan cara mengkombinasikan pemberian pupuk organik dan anorganik secara seimbang.

\section{Kelas Kesesuaian Lahan Untuk Tanaman Jagung}

Setelah membandingkan hasil pengamatan, pengukuran dan hasil analisis di Laboratorium dengan kriteria tumbuh tanaman jagung (Lampiran 10) diproleh nilai kesesuaian lahan pada lokasi penelitian seperti yang disajikan pada Tabel 13 dan 14.

Berdasarkan Tabel 13 dan 14 dapat dilihat bahwa kelas kesesuian lahan untuk tanaman Jagung di tiga belas SPL adalah sebagai berikut: kelas kesesuaian lahan pada SPL 9 memiliki kelas kesesuaian lahan sesuai marginal (S3) dengan faktor pembatas yang sangat berat yaitu fosfor (S3na-2) dankalium (S3na-3). Faktor pembatas untuk faktor pembatas $\mathrm{P}$ dan $\mathrm{K}$ dapat ditingkatkan dengan cara mengkombinasikan pemberian pupuk organik dan anorganik secara seimbang.

Pada SPL 10 memiliki kelas kesesuaian lahan sesuai marginal (S3) dengan faktor pembatas yang sangat berat yaitu fosfor (S3na-2), kalium (S3na-3) dan ( lereng (S3eh-1) faktor pembatas untuk $\mathrm{P}$ dan $\mathrm{K}$ dapat ditingkatkan dengan cara mengkombinasikan pemberian pupuk organik dan anorganik secara seimbang. Pemberian bahan organik dan pemberian pupuk anorganik dapat meningkatkan $\mathrm{pH}$ tanah, N-total, P-tersedia dan K-tersedia didalam tanah, kadar dan serapan hara $\mathrm{N}, \mathrm{P}$ dan $\mathrm{K}$ tanaman, dan meningkatkan produksi tanaman jagung (Djuniwati et al.,2003; Banuwa et al., 2003) serta meningkatkan produksi kedelai (Hermawan, 2002). sedangkan untuk faktor pembatas lereng dapat diperbaiki dengan cara usaha pembuatan teras dengan teras pematang guludan (Hidayat, 2006).

Pada SPL 12 memiliki kelas kesesuaian lahan sesuai marginal (S3) dengan faktor pembatas yang sangat berat yaitu tekstur (S3rc-1), C-organik (S3nr-4), fosfor (S3na-2), kalium (S3na-3) dan lereng (S3eh-1). Faktor pembatas untuk tekstur dan C-organik dapat diperbaiki dengan cara pemberian pupuk organik berupa kompos dan pupuk kandang, untuk $\mathrm{P}$ dan $\mathrm{K}$ dapat ditingkatkan dengan cara mengkombinasikan pemberian pupuk organik dan anorganik secara seimbang. Sedangkan untuk lereng dapat diperbaiki dengan cara pembuatan teras dengan teras bangku. Pada SPL 13 memiliki kesesuaian lahan sesuai marginal (S3) dengan faktor pembatas yang sangat berat yaitu $\mathrm{C}$ organik (S3nr-4), fosfor (S3na-2) dan kalium (S3na-3). Sedangkan untuk SPL 14 memiliki kesesuaian lahan sesuai marginal (S3) dengan faktor pembatas yang sangat berat yaitufosfor (S3na-2), kalium (S3na3), lereng (S3eh-1) dan bahaya erosi (S3eh-2). Faktor pembatas C-organik, P dan $\mathrm{K}$ dapat ditingkatkan dengan cara pemberian bahan organik berupa pupuk organik dan anorganik. Sedangkan untuk lereng dan bahaya erosi dapat diperbaiki dengan cara pembuatan teras.

Pada SPL 15 memiliki kelas kesesuaian lahan kelas tidak sesuai $(\mathrm{N})$ karena mempunyai faktor pembatas yang sangat berat dan sangat sulit untuk diatasi, dengan faktor pembatas yaitu lereng (Neh1) dan bahaya erosi (Neh-2). Pada SPL 16, SPL 17 dan SPL 18 memiliki kelas kesusaian lahan sesuai marginal (S3) dengan faktor pembatas yaitu curah hujan C-organik (S3nr-4),fosfor (S3na-2), kalium (S3na-3), lereng (S3eh-1) dan bahaya erosi (S3eh-2). C-organik dapat ditingkatkan dengan cara pemberian bahan organik, $\mathrm{P}$ dan $\mathrm{K}$ dapat ditingkatkan dengan cara pemberian pupuk. Sedangkan lereng dan bahaya erosi dapat diperbaiki dengan 
teknik konservasi pembuatan teras berupa teras bangku (Hidayat, 2006).

Pada SPL 20 dan SPL 21 memiliki kelas kesesuaian lahan sesuai marginal (S3) dengan faktor pembatas yang sangat berat yaitu C-organik (S3nr-4),fosfor (S3na-2) dan kalium (S3na-3). Faktor pembatas C-organik dapat ditingkatkan dengan cara pemberian bahan organik berupa kompos dan pupuk kandang (Hanafiah, 2007). Pada SPL 22 memiliki kelas kesesuaian lahan sesuai marginal (S3) dengan faktor pembatas yang sangat berat yaitu fosfor (S3na-2) dan kalium (S3na-3). Sedangkan pada SPL 23 memiliki kelas kesesuaian lahan sesuai marginal (S3) dengan faktor pembatas yang sangat berat yaitu fosfor (S3na-2), kalium (S3na-3), lereng (S3eh-1) dan bahaya erosi (S3eh-2). Faktor pembatas untuk $\mathrm{P}$ dan $\mathrm{K}$ dapat ditingkatkan dengan cara mengkombinasikan pupuk organik dan anorganik secara seimbang. Sedangkan untuk lereng dan bahaya erosi dapat diperbaiki dengan teknik konservasi pembuatan teras berupa teras bangku (Hidayat, 2006).

Kelas Kesesuaian Lahan Untuk Tanaman Kedelai
Setelah membandingkan hasil pengamatan, pengukuran dan hasil analisis di Laboratorium dengan kriteria tumbuh tanaman Kedelai (Lampiran 11) diproleh nilai kesesuaian lahan pada lokasi penelitian seperti yang disajikan pada Tabel 15 dan 16.

Berdasarkan Tabel 15 dan 16 dapat dilihat bahwa kelas kesesuian lahan untuk tanaman kedalai di tiga belas SPL adalah sebagai berikut : kelas kesesuaian lahan pada SPL 9 memiliki kelas kesesuaian lahan sesuai marginal (S3) dengan faktor penghambat yang sangat berat yaitu fosfor (S3na-2) dan kalium (S3na-3). Faktor pembatas untuk $\mathrm{P}$ dan $\mathrm{K}$ dapat ditingkatkan dengan mengkombinasikan pemberian pupuk organik dan anorganik secara seimbang. Pemberian bahan organik dan pemberian pupuk anorganik dapat meningkatkan $\mathrm{pH}$ tanah, N-total, P-tersedia dan K-tersedia didalam tanah, kadar dan serapan hara $\mathrm{N}, \mathrm{P}$ dan $\mathrm{K}$ tanaman, dan meningkatkan produksi tanaman jagung (Djuniwati et al.,2003; Banuwa et al., 2003) serta meningkatkan produksi kedelai (Hermawan, 2002).

Tabel 2. Hasil Evaluasi Kesesuaian Lahan untuk Jagung di DAS Krueng Pase Kabupaten Aceh Utara

\begin{tabular}{ccl}
\hline No & Satuan Peta Lahan & \multicolumn{1}{c}{ Kelas Kesesuaian Lahan } \\
\hline 1 & 9 & S3na-2,na-3 \\
2 & 10 & S3na-2,na-3,eh-1 \\
3 & 12 & S3rc-1,nr-4,na-2,na-3,eh-1 \\
4 & 13 & S3nr-4,na-2,na-3,eh-1,eh-2 \\
5 & 14 & S3nr-4,na-2,na-3,eh-1,eh-2 \\
6 & 15 & Neh-1,eh-2 \\
7 & 16 & S3na-2,na-3,eh-1,eh-2 \\
8 & 17 & S3na-2,na-3,eh-1,eh-2 \\
9 & 18 & S3nr-4,na-2,na-3,eh-1,eh-2 \\
10 & 20 & S3nr-4, na-2,na-3 \\
11 & 21 & S3nr-4, na-2,na-3 \\
12 & 22 & S3 na-2,na-3 \\
13 & 23 & S3na-2,na-3,eh-1,eh-2 \\
\hline
\end{tabular}

Keterangan: $\mathrm{rc}-1=$ tekstur, $\mathrm{nr}-4=\mathrm{C}$-organik, na- $2=$ fosfor, na-3 $=$ kalium, eh-1 $=$ Lereng, eh-2 = Bahaya Erosi. 
Tabel 3. Hasil Evaluasi Kesesuaian Lahan untuk Kedelai di DAS Krueng Pase Kabupaten Aceh Utara

\begin{tabular}{ccl}
\hline No & Satuan Peta Lahan & \multicolumn{1}{c}{ Kelas Kesesuaian Lahan } \\
\hline 1 & 9 & S3na-2,na-3 \\
2 & 10 & S3na-2,na-3,eh-1 \\
3 & 12 & S3rc-1,nr-4,na-2,na-3,eh-1 \\
4 & 13 & S3nr-4,na-2,na-3 \\
5 & 14 & S3na-2,na-3,eh-1,eh-2 \\
6 & 15 & Neh-1,eh-2 \\
7 & 16 & S3na-2,na-3,eh-1,eh-2 \\
8 & 17 & S3na-2,na-3,eh-1,eh-2 \\
9 & 18 & S3nr-4,na-2,na-3,eh-1,eh-2 \\
10 & 20 & S3nr-4,na-2,na-3 \\
11 & 21 & S3nr-4,na-2,na-3 \\
12 & 22 & S3na-2,na-3 \\
13 & 23 & S3na-2,na-3,eh-1,eh-2 \\
\hline
\end{tabular}

Keterangan: rc-1 = tekstur, nr-4 = C-organik, na-2 $=$ fosfor, na-3 = kalium, eh-1 $=$ lereng, eh-2 = Bahaya Erosi

Pada SPL 10 memiliki kelas kesesuaian lahan sesuai marginal (S3) dengan faktor pembatas yang sangat berat yaitu fosfor (S3na-2), kalium (S3na-3) dan lereng (S3eh-1). Faktor pembatas untuk P dan $\mathrm{K}$ dapat ditingkatkan dengan cara mengkombinasikan pemberian pupuk organik dan anorganik secara seimbang. Sedangkan faktor pembatas lereng dapat diperbaiki dengan cara teknik konservasi yaitu pembuatan teras.

Pada SPL 12 memiliki kelas kesesuaian lahan sesuai marginal (S3) dengan faktor pembatas yang sangat berat yaitu tekstur (S3rc-1), C-organik (S3nr-4), fosfor (S3na-2), kalium (S3na3) dan lereng (S3eh-1). Faktor pembatas untuk tekstur sangat sulit untuk diubah tetapi dapat diperbaiki dengan pemberian pupuk organik (Hardjowigeno, 2010). Upaya perbaikan untuk C-organik dapat ditingkatkan dengan cara pemberian bahan organik berupa kompos dan pupuk kandang, sedangkan untuk lereng dapat diatasi dengan cara usaha pembuatan teras (Hidayat, 2006).

Pada SPL 13 memiliki kelas kesesuaian lahan sesuai marginal (S3) dengan faktor pembatas yang sangat berat yaitu C-organik (S3nr-4), fosfor
(S3na-2) dan kalium (S3na-3). Faktor pembatas untuk C-organik, $\mathrm{P}$ dan $\mathrm{K}$ dapat diperbaiki dengan cara pemberian pupuk organik berupa kompos serta kombinasi antara pupuk organik dan anorganik. Pada SPL 14 memiliki kelas kesesuaian lahan sesuai marginal (S3) dengan faktor pembatas yang sangat berat yaitu fosfor (S3na-2), kalium (S3na-3), lereng (S3eh-1) dan bahaya erosi (S3eh-2). Faktor pembatas untuk lereng dan bahaya erosi dapat diperbaiki dengan cara teknik konservasi tanah, lereng dengan kemiringan $0-8 \%$ dapat diterapkan teknik penanaman strip yang digabung dengan penanaman mulsa menurut kontur (Suprihartono, 2003).

Pada SPL 15 memiliki kelas kesesuaian lahan tidak sesuai $(\mathrm{N})$ karena mempunyai faktor pembatas yang sangat berat dan sangat sulit untuk diatasi, dengan faktor pembatas lereng (Neh-1) dan bahaya erosi (Neh-2). Pada SPL 16 dan SPL 17 memiliki kelas memiliki kelas kesesuaian lahan sesuai marginal (S3) dengan faktor pembatas yang sangat berat yaitu fosfor (S3na-2), kalium (S3na-3), lereng (S3eh-1) dan bahaya erosi (S3eh-2). Faktor pembatas untuk lereng dan bahaya erosi dapat diperbaiki 
dengan teknik konservasi pembuatan teras berupa teras bangku. Sedangkan pada SPL 18, SPL 20 dan SPL 21 memiliki kelas memiliki kelas kesesuaian lahan sesuai marginal (S3) dengan faktor pembatas yang sangat berat C-organik (S3nr-4),fosfor (S3na-2) dan kalium (S3na-3).Faktor pembatas untuk $\mathrm{P}$ dan $\mathrm{K}$ dapat diperbaiki dengan cara pemberian pupuk organik dan anorganik dengan cara mengkombinasikan secara seimbang. Sedangkan faktor pembatas untuk Corganik dapat ditingkatkan dengan cara pemberian bahan organik berupa kompos dan pupuk kandang (Hanafiah, 2005).

Pada SPL 22 memiliki kelas kesesuaian lahan sesuai marginal (S3) dengan faktor pembatas yang sangat berat yaitu fosfor (S3na-2) dan kalium (S3na-3). Faktor pembatas untuk $\mathrm{P}$ dan $\mathrm{K}$ dapat diperbaiki dengan cara pemberian pupuk organik dan anorganik dengan cara mengkombinasikan secara seimbang. Pada SPL 23 memiliki kelas kesesuaian lahan sesuai marginal (S3) dengan faktor pembatas yang sangat berat yaitu fosfor (S3na-2), kalium (S3na-3), lereng (Neh-1) dan bahaya erosi (Neh-2). ). Faktor pembatas untuk lereng dan bahaya erosi dapat diperbaiki dengan cara teknik konservasi tanah, lereng dengan kemiringan $0-8 \%$ dapat diterapkan teknik penanaman strip yang digabung dengan penanaman mulsa menurut kontur.

\section{Usaha Perbaikan Kesesuaian Lahan}

Ada beberapa faktor pembatas yang dapat dibedakan menjadi dua jenis yaitu (1) faktor pembatas yang sifatnya permanen atau tidak ekonomis untuk diperbaiki seperti temperature, curah hujan, lamanya masa kering dan kelembaban. Hal ini sesuai dengan pendapat Rayes (2007) yang menyatakan bahwa dalam evaluasi lahan faktor ketinggian tempat yang merupakan rezim suhu, kelembaban tidak dapat diperbaiki dengan teknologi yang ada
(2) faktor pembatas yang dapat diperbaiki dan secara ekonomis masih menguntungkan dengan cara memasukkan teknologi yang tepat seperti: drainase, media perakaran, retensi hara, ketersediaaan hara, bahaya banjir, toksisitas, bahaya erosi (Hardjowigeno dan Widiatmaka, 2007).

Faktor pembatas di setiap SPL yang dapat diperbaiki seperti berikut :

\section{- Drainase}

Adapun Usaha atau cara yang dapat dilakukan untukmemperbaiki drainase adalah dengan cara melakukan tindakan perbaikan pada sistem drainase dengan pembuatan saluran drainase yang baik dan benar, yaitu dengan cara pembuatan parit. Dimana saluran pembuangan air (waterway) dibangun menurut arah lereng dan merupakan saluran pembuangan air aliran permukaan. Drainase juga dapat diperbaiki dengan pembuatan parit-parit yang dalam dan sempit. Biasanya untuk pengendalian hilangnya air dari tanah sebelum air masuk kedalam tanah (Suripin, 2004).

\section{- Tekstur}

Tekstur tanah tidak dapat diubah, tetapi bisa diperbaiki dengan cara penambahan pupuk organik berupa kompos dan pupuk kandang. Pengaruh bahan organik terhadap tanah dan tanaman adalah sebagai berikut: sebagai granulator yaitu untuk memperbaiki struktur tanah, sebagai unsur hara bagi tanaman, menahan kemampuan tanah untuk menahan unsur hara (Kapasitas Tukar Kation menjadi tinggi), sebagai sumber eneri bagi mikroorganisme, menambah kemampuan tanah untuk menahan air (Hardjowigeno, 2010).

\section{- C-organik (Karbon Organik)}

Adapun upaya yang dilakukan untuk meningkatkan C-organik didalam tanah adalah dengan memberikan bahan organik berupa pupuk kompos dan juga pupuk kandang dengan cara di tebar. Pupuk kompos berasal dari hasil 
pengolahan sisa-sisa tanaman yang mengandung banyak mikroorganisme. Sementara pupuk kandang berasal dari hasil pengolahan kotoran hewan yang berfungsi untuk menggemburkan lapisan tanah dipermukaan, meningkatkan populasi jasad renik, dan mempertinggi daya serap dan daya simpan air.

Menurut (Hanafiah, 2014) bahan organik merupakan sumber senyawasenyawa organik yang dapat diserap oleh tanaman meskipun dalam jumlah sedikit, seperti alanine, glisin dan asam amino lainnya, juga hormone/zat perangsang tumbuh dan vitamin. Secara fisik biomass (bahan organik) berperan untuk mempengaruhi warna tanah menjadi coklat-hitam, merangsang granulasi, memperbaiki struktur tanah menjadi lebih remah dan meningkatkan daya tanah dan menahan air sehingga drainase tidak berlebihan, kelembaban dan temperature tanah menjadi stabil.

\section{- Fosfor dan Kalium}

Adapun upaya yang dilakukan untuk meningkatkan fosfor dan kalium agar tepat dosis dan tepat sasaran yaitu dengan cara pemberian bahan organik berupa pupuk kandang dan sisa tanaman sebanyak 20 ton/ha, yang dilakukan satu sampai dua minggu sebelum tanam (MST) dengan cara di tebar, kemudian disertai dengan pemberian pupuk anorganik NPK dengan dosis N (urea) $200 \mathrm{~kg} / \mathrm{ha}, \mathrm{SP}-36200 \mathrm{~kg} / \mathrm{ha}$ dan KCL $100 \mathrm{~kg} / \mathrm{ha}$. Untuk pemberian N (Urea) diberikan 2 kali yaitu masing-masing $1 / 2$ pada saat tanam dan umur 14 hari setelah tanam (HST), sedangkan untuk SP-36 dan KCL diberikan sekaligus pada saat tanam. Pemberian bahan organik 20 ton/ha yang disertai pupuk NPK dengan dosis (Urea $200 \mathrm{~kg} / \mathrm{ha}$, SP-36 $200 \mathrm{~kg} / \mathrm{ha}$ dan KCL $100 \mathrm{~kg} / \mathrm{ha}$ ) berpengaruh nyata terhadap jumlah daun, bobot basah, bobot kering dan kadar K-tanah (Rahman et al., 2008).

Penggunaan pupuk organik dan anorganik yang dikombinasikan begitu penting dalam pertanian berkelanjutan, karena setiap jenis pupuk memiliki kelebihan dan kelemahan masing-masing yang dapat saling melengkapi dan memperbaiki sehingga didapatkan hasil usaha tani yang tinggi namun keadaan lahan dan lingkungan yang tetap terjaga kualitasnya demi keberlanjutan sistem pertanian. Pemberian bahan organik dan pemberian pupuk anorganik dapat meningkatkan $\mathrm{pH}$ tanah, N-total, Ptersedia dan K-tersedia didalam tanah, kadar dan serapan hara N, P dan K tanaman, dan meningkatkan produksi tanaman jagung (Djuniwati et al.,2003; Banuwa et al., 2003) serta meningkatkan produksi kedelai (Hermawan, 2002).

\section{- Lereng dan Bahaya Erosi}

Adapun usaha perbaikan yang dapat dilakukan untuk memperbaiki kondisi lereng dan bahaya erosi yaitu dengan melakukan teknik konservasi dengan metode mekanik dan vegetatif, yaitu dengan pembuatan Guludan dan guludan bersaluran, pembuatan teras menurut kontur serta penggunaan tanaman penutup tanah seperti Leguminosa Cover Crop (LCC) dan mulsa. Pembuatan guludan dan guludan bersaluran dilakukan pada lereng 8 sampai $12 \%$ atau tanah yang peka erosi dengan membuat tumpukan tanah yang memanjang menurutarah garis kontur atau memotong lereng serta diperkuat dengan penanaman tanaman penutup tanah (cover crop) selain untuk mencegah dan mengendalikan bahaya erosi juga berfungsi untuk menahan air hujan agar tidak langsung mengenai permukaan tanah, menambah kesuburan tanah (sebagai pupuk hijau). Metode penanamannya dapat rapat, barisan maupun menurut kontur, dengan demikian maka erosi berkurang (Arsyad, 2010).

Sedangkan untuk pembuatan teras menurut kontur dapat dilakukan pada Lereng dengan kemiringan 15$30 \%$. Namun usaha ini perlu tenaga dan modal yang relative besar untuk pembuatannya. Pada pengolahan tanah 
dengan pembajakan tanah dilakukan menurut garis kontur atau memotong lereng, sehingga terbentuk jalur tumpukan tanah dan alur diantara tumpukan tanah yang terbentang menurut kontur. Pengolahan menurut kontur akan lebih efektif jika diikuti dengan penanaman menurut kontur, yaitu barisan tanaman diatur sejalan dengan garis kontur.

Keuntungan utama pembuatan teras menurut kontur adalah terbentuknya penghambat aliran permukaan yang meningkatkan penyerapan air oleh tanah dan menghindari pengangkutan tanah. Oleh karena itu di daerah beriklim kering, pengolahan menurut kontur juga sangat efektif untuk konservasi air (Arsyad, 2010).

\section{Simpulan}

Kelas kesesuaian lahan untuk padi sawah tadah hujan di empat SPL terdiri dari kelas sesuai marginal (S3). Dengan faktor pembatas drainase (S3oa-1), fosfor (S3na-2), kalium (S3na-3), lereng (S3eh-1) dan bahaya erosi (S3eh-2), yang terdapat pada SPL 29, SPL 30, dan SPL 31. Sedangkan pada SPL 26 memiliki kelas kesesuaian lahan tidak sesuai (N) dengan faktor pembatas lereng (Neh-1) dan bahaya erosi (Neh-2). Adapun usaha perbaikan yang dapat di lakukan yaitu dengan cara pembuatan saluran drainase yang dalam dan sempit, pemberian pupuk organik dan anorganik dengan cara mengkombinasi, serta pembuatan teras menurut arah kontur dengan penanaman penutup tanah.

Kelas kesesuaian lahan untuk tanaman Jagung dan Kedelai di tiga belas SPL terdiri dari kelas sesuai marginal (S3). Dengan faktor pembatas yaitu tekstur (S3rc-1), C-organik (S3nr4), fosfor (S3na-2), kalium (S3na-3), lereng (S3eh-1) dan bahaya erosi (S3eh2), yang terdapat pada SPL 9, SPL 10, SPL 12, SPL 13, SPL 14, SPL 16, SPL 17, SPL 18, SPL 20, SPL 21, SPL 22 dan SPL 23. Sedangkan pada SPL 15 memiliki kelas kesesuaian lahan tidak sesuai (N) dengan faktor pembatas lereng (Neh-1) dan bahaya erosi (Neh-2). Adapun usaha perbaikan yang dapat di lakukan yaitu dengan cara pembuatan saluran drainase yang dalam dan sempit, pemberian pupuk organik dan anorganik dengan cara mengkombinasi, serta pembuatan teras menurut arah kontur dengan penanaman penutup tanah.

\section{Daftar Pustaka}

Abdullah, T. S. 1993. Survai Tanah dan Evaluasi Lahan. Penebar Swadaya, Jakarta.

Arsyad, S. 2010. Konservasi Tanah dan Air. IPB Press. Bogor.

Asdak, C. 2010. Hidrologi dan Pengelolaan Daerah Aliran Sungai. Edisi kelima.Yogyakarta : Gadjah Mada University Press.

Atman. 2006. Budidaya Kedelai di Lahan Sawah Sumatera Barat. Jurnal Ilmiah Tambua. 5 (3):288296.

Banuwa, I. S., Pulung, M. A., dan Utomo, M. 2003. Pengaruh pemberian sisor (night soil) terhadap serapan NPK dan hasil serapan jagung (Zea mays $L$ ). $J$. Tanah Trop., $16: 111-113$.

Basyaruddin. 2013. Pengelolaan Tanah dan Air " Memelihara Produktifitas Tanah dan Kualitas Air". Cita pustaka Media Perintis, Bandung.

[BMKG] Badan Meteorologi Klimatologi dan Geofisika Aceh Utara. 2014. Data Iklim.

[BPDAS] Badan Pengelolaan Daerah Aliran Sungai Provinsi Aceh. 2011. Data Hidrologi DAS Krueng Pase tahun 2011.

[BPS] Badan Pusat Statistik Aceh, 2015. Produksi Padi dan Palawija Provinsi Aceh.

Direktorat Jendral Bina Produksi Tanaman Pangan. 2002. Program 
Pengembangan Produksi Jagung Nasional. Makalah disampaikan pada National Maize Research and Development Prioritization workshop 15 - 17 Mei 2002 di Malino Sulawesi Selatan.

Djaenudin, D., Marwan, H., Subagjo, H., Mulyani, A., dan Suharta, N. 2000.

Kriteria Kesesuaian Lahan Untuk Komoditas Pertanian. Pusat Penelitian Tanah dan Agroklimat, Bogor.

Djaenudin, D., Marwan H., Subagyo H., Komoditas Pertanian. Edisi dan A. Hidayat. 2003. Petunjuk Teknis untuk Pertama tahun 2003, ISBN 979-9474-25-6. Balai Penelitian Tanah, Pusat Penelitian dan Pengembangan Tanah dan Agroklimat, Bogor, Indonesia.

Djaenudin, D., Marwan, H., Subagjo, H., dan Hidayat, A. 2011. Petunjuk Teknis Evaluasi Lahan Untuk Komoditas Pertanian. Balai Besar Litbang Sumberdaya Lahan Pertanian, Badan Litbang Pertanian, Bogor. 165p.

Djuniwati, S., Hartono, A., dan Indriyati, L.T. 2003. Pengaruh bahan organik (Peuraria javanica) dan fosfat alam terhadap pertumbuhan dan serapan $\mathrm{P}$ tanaman jagung (Zea mays) pada Andisol pasir sarongge. Jurnal Tanah dan Lingkungan, 5 :16 - 22.

[Dephut] Departemen Kehutanan. 2009 b. Peraturan Menteri Kehutanan RI No:P. 39/Menhut-II/2009 tentang Pedoman Penyusunan Rencana Pengelolaan Daerah Aliran Sungai Terpadu. Jakarta: Departemen Kehutanan RI.

[Dephut] Departemen Kehutanan. 2001. Keputusan Menteri Kehutanan No:52/Kpts-II/2001 tentang Pedoman Penyelenggaraan Pengelolaan Daerah Aliran Sungai. Jakarta: Departemen Kehutanan RI.
Effendi, E. 2007. Kajian Model Pengelolaan Daerah Aliran Sungai (DAS) Terpadu. (cited 2013 Des.3). Published by Andi Prasetyo. Available from: http://www.scribd.com/doc/52831 935. Diakses tanggal 6 juni 2016.

Fauzi, Y. Boko, S. Zulfia, M. 2009. Analisis Kesesuaian Lahan Wilayah Pesisir Kota Bengkulu Melalui Perancangan Model Spasial dan Sistem Informasi Geografis (SIG). Forum Geografi. $23(2): 101-111$.

[FAO] Food And Agriculture. 1976. A Framework for land Evaluation. Soil Resources Development and Conservation Service Land Water Development Divition Food And Agriculture Organization of United Nations.

Hanafiah, A. 2005. Dasar Dasar Ilmu Tanah. Raja Grafindo Persada, Jakarta.

\section{. 2014. Dasar-dasar Ilmu}

Tanah. PT. Raja Grafindo Persada, Jakarta.

Handoko. 1995. Klimatologi Dasar. Pustaka Jaya. Bogor. 192p.

Hardjowigeno, S. 2010. Ilmu Tanah. Akademika Pressindo. Jakarta.

Hardjowigeno, S., dan Luthfi, M. 2005. Tanah Sawah. Malang (ID): Bayu media Publishing.

Hardjowigeno, S., dan Widiatmaka. 2007. Evaluasi Kesesuaian Lahan dan Perencanaan Tata Guna Lahan. Gadjah Mada University Press, Yogyakarta.

Hardjowigeno, S., dan Widiatmaka. 2001. Kesesuian Lahan dan Perencanaan Tata Guna Lahan. Jurusan Tanah Fakultas Pertanian. Institut Pertanian Bogor.

Hermawan, A. 2002. Pemberian kompos isi rumen-abu sekam padi dan NPK terhadap beberapa karakteristik kimia tanah Ultisol dan keragaan tanaman kedelai. Jurnal. Tanah Tropika. 15: 7-13. 
Hidayat, M.Y. 2006. Evaluasi Kesesuaian Lahan untuk Tanaman Sengon (Paraserianthes falcataria (L) Nielsen) pada beberapa satuan kelas lereng. Program Studi Budidaya Hutan Fakultas Kehutanan Institut Pertanian Bogor.

Juarti. 2004. Konservasi Lahan dan Air. Malang: UM Press.

[Kemenhut] Kementerian Kehutanan. 2013. Keputusan Direktur Jenderal Bina pengelolaan Daerah Aliran Sungai Kementerian Kehutanan Nomor: P.3/Kpts-II/2013 tentang Pedoman Identifikasi Karekteristik $D A S$. Jakarta: Kementerian Kehutanan RI.

[Kemtan] Kementerian Pertanian. 2015. Outlook Komoditas Pertanian Subsektor Tanaman Pangan Jagung. Jakarta: Pusdatin Kementerian Pertanian.

Kurnia, U. Agus, F. Adimihardja, A. Dariah, A. 2006. Sifat Fisik

Tanah dan Metode Analisisnya. Balai Besar Penelitian dan Pengembangan Sumber Daya Lahan Pertanian. Bogor.

Lehmann, A., dan Stahr, K. 2010. The potential of soil functions and planner-oriented soil evaluation to achieve sustainable land use. Jurnal Soils Sediments, 10:10921102.

Marwoto. 2010. Peningkatan Produksi Kedelai Melalui Pengelolaan Tanaman Terpadu. Buletin Palawija. 20: 62-71.

Masganti, J. Barus. Hafif, B. 2013. Zoning rural area for the development of annual plants. International Journal on Advanced Science Engineering Information Technology, 3(1):33- 37.

Makaborang, M., Goenadi, S., Hadi, P. 2009. Optimalisasi penggunaan lahan berdasarkan kelas kesesuaian lahan untuk pengembangan tanaman perkebunan (Studi Kasus :Kabupaten Sumba Timur Provinsi Nusa Tenggara Timur). Jurnal Agritech, 29(4):188-197.

Novizan. 2002. Petunjuk Pemupukan yang Efektif. Agro Media Pustaka. Jakarta 84 hal.

Pane, H. 2001. "Ancaman Baru Dalam Sistem Produksi Padi di Lahan Sawah Tadah Hujan". Dalam Prosiding Seminar Nasional Budidaya Tanaman Pangan Berwawasan Lingkungan. Pusat Penelitian dan Pengembangan Tanaman Pangan. Bogor. Hal. 176 $-182$

Pirngadi, K. dan Makarim, K., A. 2006. Peningkatan Produktivitas Padi pada Lahan Sawah Tadah Hujan melalui Pengelolaan Tanaman Terpadu. Penelitian Pertanian Tanaman Pangan. 25 ( 2) :116123.

Puntodewo, A., Dewi, S., Tarigan, J. Sistem Informasi Geografis untuk Pengelolaan Sumber Daya Alam. www.google books [10 Juni 2010]. Diakses pada tanggal 6 juni 2016.

Purwono dan Hartono, R. 2007. Bertanam Jagung Unggul. Penebar Swadaya, Jakarta.

[Puslitbangtanak] Pusat Penelitian dan Pengembangan Tanah dan Agroklimat 2003. Pengembangan Lahan Sawah Mendukung Pengembangan Agribisnis Berbasis Tanaman Pangan. Bogor.

Rachman, I. A., Djuniwati, S., dan Idris, K. 2008. Pengaruh Bahan Organik dan Pupuk NPK Terhadap Serapan Hara Dan Produksi Jagung di Inceptisol Ternate. Jurnal Tanah dan Lingkungan. 10 (1) : 7-13.

Rahmawaty. 2009. Penggunaan Geographic Information System (GIS) untuk Pemetaan Kesesuaian Lahan di DAS Besitang. Prosiding. Optimalisasi Pengelolaan Lahan dalam Upaya Menekan Pemanasan 
Global Mendukung Pendidikan Berbasis Pembangunan Berkelanjutan. 12-13 Februari 2010. Medan. Hal:113-119.

Rayes, M. L. 2007. Metode Inventarisasi

Sumber Daya Lahan. Penerbit Andi, Yogyakarta.

Ritung, S., Wahyunto., Agus F., dan Hidayat H. 2007. Panduan Evaluasi Kesesuaian Lahan Dengan Contoh Peta Arahan Penggunaan Lahan Kabupaten Aceh Barat. Balai Penelitian Tanah dan World Agroforestry Centre (ICRAF), Bogor, Indonesia

Ritung, S., Nugroho., Mulyani, A., dan Suryani, E. 2011. Petunjuk Teknis Evaluasi Lahan Untuk Komoditas Pertanian (Edisi Revisi). Balai Besar Penelitian dan Pengembangan Sumberdaya Lahan Pertanian, Badan Penelitian dan Pengembangan Pertanian, Bogor. 168 hal.

Saridevi. 2013. Perbedaan sifat biologi tanah pada berbagai tipe penggunaan lahan di tanah Andisol, Inceptisol, danVertisol. Jurnal Agroekoteknologi Tropika (2). $1: 88-95$

Seta, A. K. 1995. Konservasi Sumber Daya Tanah dan air. Kalam, Jakarta

Seyhan, E. 1990. Dasar-Dasar Hidrologi. Gadjah Mada University Press: Yogyakarta.

Sitorus, S. R. P. 2004. Evaluasi Sumber Daya Lahan. Tarsito. Bandung

Soemarno. 2001. Sumberdaya Tanah dan Kesesuaiannya untuk Pertanian. Universitas Brawijaya. Malang.

Sofyan, A., Nursyamsi, D. dan Amien, I. 2003. Development of Soil Testing in Indonesia. SMCRSP-Technical Bulletin (01) 2001.

Supangat, A. B., Haryono, S., Putu., dan Erny. 2013. Status Kesuburan Tanah di Bawah Tegakan Eucalyptus Pellita F.Muell :( Studi Kasus di HPHTI PT. Arara Abadi,
Riau). Jurnal Manusia dan Lingkungan 20 (1) : 22-34. Fakultas Kehutanan UGM. Bandung.

Suprihartono, D. 2003. Evaluasi Kesesuaian Lahan Beberapa Pedon di Kabupaten Probolinggo Untuk Tanaman Mangga (Mangifera Indica) [Skripsi]. Fakultas Pertanian, Institut Pertanian Bogor, Bogor.

Suripin. 2004. Pelestarian Sumber Daya Tanah dan Air. Andi Offset Yogyakarta, Yogyakarta.

Suwandi. 2015. Outlook Komoditas Pertanian Tanaman Pangan Kedelai. Pusat Data dan

Sistem Informasi Pertanian. Jakarta. 